\title{
АНАЛІЗ ЖИТТЕВОГО ЦИКЛУ ВІТРОЕНЕРГЕТИЧНИХ УСТАНОВОК У КОМПАРТМЕНТАХ СКЛАДНОГО ЛАНДШАФТНОГО КОМПЛЕКСУ
}

\author{
Руда М. В., Гивлюд А. М.
}

\section{ВСТУП}

Швидке зростання світового енергоспоживання призводить до посилення впливу енергетики на навколишнє середовище, порушення теплового балансу атмосфери і глобальних змін клімату ${ }^{1}$. Разом із тим методологічний підхід до оцінки впливу вітроенергетичної установки (BEУ) на компоненти навколишнього природного середовища, який можна було б використати для цілей дослідження, все ще залишаються ненапропрацьованими ${ }^{2}$.

Актуальність цього дослідження пов'язана з тим, що, з одного боку, розвиток відновних джерел енергії розглядається як один із стратегічних напрямів, а 3 іншого - 3 тим, що вони володіють низкою недоліків та потенційних впливів на стан навколишнього природного середовища. Стосовно ВЕУ ці впливи проявляються в процесі будівництва генеруючих об'єктів на відновних джерелах енергії, виробництва електрогенеруючого обладнання, в результаті чого здійснюються викиди шкідливих речовин в атмосферу, споживання великих об'ємів води, викопних мінеральних ресурсів, що супроводжується утворенням промислових відходів ${ }^{3}$ Тому дослідження, націлені на оцінку комплексних екологічних ефектів відновлювальної енергетики за методикою аналізу життєвого циклу (АЖЦ) залишаються особливо актуальними ${ }^{4}$.

1 Перспективы мировой ветроэнергетики. Доклад GWEC, Greenpeace International, DLR и Ecofys Cpnsultancy / под ред. Crispin Aubrey, Angelika Pullen, Arthouros Zervos, Sven Teske, Berlin. 2007. 31 c.

Алёшин Д.В. Проблемы развития альтернативной энергетики: правовой аспект. Журнал ЭГО. 2012. № 3. С. 10-12.

3 Леже С. «Зеленая лихорадка»: инвестиции в новую енергетику. Вестник McKinsey. 2008. № 3. C. 10-15.

Ратнер С.В., Иосифов В.В. Формирование рынков энергетического машиностроения в Китае и Индии. Вестник УРФУ, Серия «Экономика и управление». 2013. № 3. С. 52-62. 
Згідно 3 методикою АЖЦ, викладеною в стандартах ISO $14041: 1999^{5}, 14044: 2006^{6}$, кожен продукт або послуга проходить низку стадій розвитку, які в сукупності становлять його/їі «життєвий цикл». Залежно від природи продукту/послуги екологічний вплив може проявлятись по-різному, наприклад, як виснаження озонового газу, парниковий ефект, окислення грунту і втрата біорізноманіття тощо . Планета Земля $\epsilon$ замкненою системою матеріальних потоків (на противагу енергетичним потокам) ${ }^{8}$.

У сучасному соціально-економічному середовищі матеріальні потоки і процеси відбуваються за лінійною схемою. Але на нескінченному відрізку часу матеріали, що пройшли через техносферу, заново повертаються у навколишне середовище як сировина . Концепція життєвого циклу розглядає продукти/послуги з початку їх фізичного виникнення і до моменту припинення їх функціонування.

\section{1. Аналіз літературних даних та постановка проблеми}

У роботах $^{10,11}$ досліджено, що в останні десятиліття світ зіткнувся 3 двома серйозними проблемами в галузі енергетики: це забезпечення надійності енергопостачання i боротьба 3 негативним впливом виробництва енергії на навколишнє середовище, як у районах розміщення джерел генерації, так і в масштабах всієї планети.

У роботі $^{12}$ встановлено, що метод оцінювання життєвого циклу (Life-Cycle assessment, LCA) грунтується на серії ISO-стандартів i $\epsilon$ одним із провідних методів оцінки потенційних впливів

${ }^{5}$ Muñoz I, Schmidt J, Brandão M, Weidema B P. Rebuttal To 'Indirect Land Use Change (Iluc) Within Life Cycle Assessment (Lca) - Scientific Robustness And Consistency With International Standards'. Gcb Bioenergy, Letter To Editor, 7(4), 2015. P. 565-566.

${ }^{6}$ Weidema B P. Attributional And Consequential Interpretations Of The Iso 14044. Historical Snapshot From The Work In Iso. 2018. Tc207/Sc5/Tg1.

${ }_{7}^{7}$ Nishioka Y., Levy J.I, Norris G.A, Wilson A, Hofstetter P, Spengler J D. Integrating Risk Assessment And Life Cycle Assessment: A Case Study Of Insulation. Risk Analysis 22(5). 2002. P. 1003-1017.

Бойко Т.Г., Руда М.В., Паславський М.М., Соколов С. О., Петренко С.В., Скаковський C.I. Кібернетична природа складних ландшафтних комплексів та супра-оптимізація механізмів самовідновлення та самозбереження. Науковий вісник НЛТУ Украӥни : збірник науково-технічних праць. 2019. Т. 29, № 5. С. 134-140.

9 Obshta, Anatoliy; Bubela, Tetiana; Ruda, Maria; Kochan, Roman The Model of Environmental Assessment of Complex Landscape Systems. International Multidisciplinary Scientific GeoConference : SGEM; Sofia Том 18, Изд. 3.2, : 973-979. Sofia: Surveying Geology \& Mining Ecology Management (SGEM). (2018)DOI:10.5593/sgem2018/3.2/S14.125.

10 Безруких П.П. Использование энергии ветра. Техника, экономика, экология. Москва : Колос, 2008. 196 с.

11 Ветроэнергетика / под ред. Д. де Рензо; пер. с англ. Зубарева В.В. и Дранкфурта М.О.; под. ред. Шефтера Я.И. Москва : Энергоатомиздат, 2010. 287 с.

${ }_{12}$ Cleary B. Using life cycle assessment ro compare wind energy infrastructure / B. Cleary, A. Duffy, A. O'Connor. Proceedings of International Symposium on Life Cycle Assessment and Construction. 2012. P. 31-39. 
ВEУ на навколишне середовище. Такий підхід був використаний i удослідженнях багатьох інших вчених ${ }^{13,14,15,16}$, а також одним iз найбільших виробників вітряних турбін - датською компанією Vestas ${ }^{17}$. Дедалі більше державних організацій, компаній і наукових установ застосовують методику АЖЦ у процесі прийняття рішень та для розробки планів розвитку як окремих продуктів, так і цілих секторів економіки. Однією $з$ таких компаній є і EcoIvent ${ }^{18}$, база даних якої містить добре документовані дані процесів для тисячі продуктів, вона вміщує близько 10300 наборів даних для різних виробничих процесів $\mathrm{i}$ використовується у великому спектрі екологічних досліджень. У цій роботі дані з цієї бази використовувались лише для верифікації власних результатів, оскільки EcoIvent має у своєму розпорядженні масив даних екологічних ефектів наземної вітрової енергетики у світі.

Проте, якщо аналізувати праці 3 цієї тематики ${ }^{19,20}$,залишились невирішені питання, пов'язані з відсутністю досліджень щодо певних видів екологічного впливу нетрадиційних та відновлюваних джерел енергії на навколишне середовище в часовому аспекті. Такі питання залишаються невивченими і розробленими ще меншою мірою, ніж технічні питання використання цих джерел енергії. Причиною цього можуть бути труднощі 3 встановленням такого впливу, адже він передбачає здійснення дослідження впливу ВЕУ під час його безпосередньої експлуатації.

Аналіз літературних джерел ${ }^{21,22}$ дав змогу виявити, що проблемами альтернативної енергетики переважно займаються в технічному плані, вивчаючи питання подальшого вдосконалення конструкції і технологій використання вітроенергетичних установок. Однак варто зауважити, що питання впливу об'єктів вітроенергетики на компоненти довкілля,

${ }^{13}$ Life cycle assessment of a multi-megawatt wind turbine / E. Martinez, F. Sanz, S. Pellegrini [et. Al]. Renewable Energy. 2009. № 34(3). P. 667-673.

${ }^{14}$ Chenai Ch. Life cycle analysis of wind turbine. Sustainable Development. Energy, Engineering and Technologies. Manufacturing and Environment. 2012.

15 Toth T. Anthropogeomorphologic impacts of onshore and offshore wind farms / T. Toth, S. Szegedi. Acta climatologica et chorologica. 2007. № 40-41. P. 147-154.

16 Єрмоленко Б.В., Ермоленко Г.В., Рыженков М.А. Экологические аспекты вітроенергетики. Теплоэнергетика. 2011. № 11. С. 72-78.

${ }_{17}$ Final Report. Life Cycle Assessment Of Electricity Production from a Vestas V112 Turbine Wind Plant. 2011. URL: http://www.vestas.com.

${ }_{18}^{18}$ База даних «EcoIvent». URL: http://www.ecoivent.org/.

${ }^{19}$ Burton T., Sharpe D., Jenkins N., Bossanyi E. (2001), Wind energy. Handbook. I [West Sussex], England, 643 p.

${ }_{20}$ Chmielniak, T. (2008). Technologie energetyczne. Warszawa. Wydawnictwa NaukowoTechniczne. 564 p.

21 Забарний Г.М. Енергетичний потенціал нетрадиційних джерел енергії України / Г.М. Забарний, А.В. Щурчков. Київ : ІТТФ, 2002. С. 151-159.

${ }_{22}$ Der Strommix in Deutschland im Jahr 2012. AGEB. URL: http://www.unendlichviel-energie.de. 
висвітлені неповною мірою i в наукових дослідженнях екологів практично не розглядаються.

Все це дає змогу стверджувати, що доцільним $є$ проведення АЖЦ ВЕУ 3 виявленням потенційних впливів на яруси підсистеми компартментів складного ландшафтного комплексу (СЛК) на всіх етапах його функціонування - від етапу видобутку корисних копалин для виготовлення складових частин до моменту повної утилізації вітрової турбіни після закінчення терміну їі експлуатації. Пропонований підхід можна здійснити за допомогою імітаційного моделювання ще до введення в експлуатацію ВЕУ.

Метою дослідження є аналіз оцінювання впливу вітроенергетичних установок на всіх етапах життєвого циклу в компартментах складного ландшафтного комплексу.

\section{2. Матеріали та методи досліджень життєвого циклу вітроенергетичних установок}

Для оцінювання впливу ВЕУ на всіх етапах життєвого циклу використовували програмне забезпечення SimaPro, яке є професійним інструментом для збору, аналізу та моніторингу екологічних характеристик продуктів і послуг.

Програмне забезпечення (П3) SimaPro дає змогу аналізувати продукти з урахуванням сценаріїв поводження з відходами, який можна моделювати самостійно, залежно від обраного продукту/послуги. Життєвий цикл містить сценарії поводження 3 відходами 3 відсотковими частками кожного етапу (наприклад рециклінг, захоронення i т.д.) у загальному сценарії або один сценарій їх захоронення на сміттєзвалищі. Оскільки демонтаж передбачає остаточне закриття вітрового парку та утилізацію комплектуючих, змодельовані наслідки ймовірної фіторемедіації території.

\section{3. Результати досліджень життсвого циклу вітроенергетичних установок в компартментах складного ландшафтного комплексу}

Дослідження впливу ВЕУ на компоненти довкілля були проведені 3 урахуванням багатьох параметрів, у т.ч. і технічних характеристик вищевказаних установок. Будівництво вітрової електростанції (ВЕС) загальною потужністю $120 \mathrm{MB}$ із необхідною інфраструктурою (в тому числі під'їзні дороги, підземні кабельні лінії електропередач 110 кВ та підземні кабельні мережі 35 кВ, розподільчі пункти та підстанція) передбачено здійснити на окремо розташованих земельних ділянках загальною площею 30,6041 га в межах земельних ділянок, площа територій під ВЕУ 28,259 га в межах земельних ділянок. У рамках реалізації будівництва ВЕС із необхідною інфраструктурою передбачається встановлення 34 сучасних вітрових електричних установок (ВЕУ), електричної підстанції - ПС 35/110 кВ «ВЕС 
Воловець», трьох розподільчих пунктів (РП), у складі яких закриті розподільчі пристрої та підземної кабельної лінії електропередачі 3 напругою 35 кВ та 110 кВ. Встановлена потужність ВЕС із необхідною інфраструктурою - 120 МВт. Орієнтовний термін експлуатації ВЕУ - 25 років (термін експлуатації може бути продовжений залежно від технічних характеристик обраного типу основного обладнання ВЕС), а споруд ВЕС - від 60 до 100 років.

Основним обладнанням для цього проекту $\epsilon$ вітрові турбіни. Зважаючи на вітрові та погодні умови на території планованої діяльності, а також шумові, вібраційні та інші характеристики, Замовник на етапі розробки проектної документації вибрав ВЕУ фірми «Siemens SWT DD-142». Вітроустановки мають відповідні сертифікати якості за міжнародними стандартами ISO 9001 та IEC 61400-12-1.

Згідно 3 намірами Замовника та проектного рішення детального плану території, запроектована ВЕС складається з окремих ділянок із розташуванням на них споруд, а саме: вітроустановок (ВЕУ), площа окремої ділянки для одної турбіни становить $0,53-1$ га; розподільчих пунктів (РП) із ділянками площею $0,245-0,81$ га; ремонтноексплуатаційної бази (РЕБ) 3 системою управління роботою ВЕС; тимчасових майданчиків для зберігання обладнання і техніки; опор ліній електропередач та підземних кабельних і комунікаційних ліній (КЛ); технологічних проїздів, сполучних між ВЕУ доріг тощо.

До числа стаціонарних об'єктів ВЕС входять: система управління роботою ВЕС, споруди РЕБ та РП з силовим обладнанням та інженерними комунікаціями, фундаменти башт, башти (із сходами, поворотними механізмами, гондолами, електричними генераторами, системами спостереження за напрямом та зміною кута атаки вітру, трансформаторами, гальмовими системами, трансмісіями, лопатями, системами пожежогасіння, телекомунікаційними системами для передачі даних про роботу вітрогенераторів, системами захисту від блискавки), опори та повітряні і кабельні підземні лінії, під'їзні шляхи, інші допоміжні споруди та інженерні комунікації, необхідні для роботи ВEC, а також забезпечення життєдіяльності обслуговуючого персоналу.

Іншу категорію становить земля, тимчасово використовувана для зберігання деталей конструкцій.

У процесі розміщення ВЕУ враховувалась наявність доріг для транспортування обладнання та можливість організації під'їздів до ВЕУ $з$ метою максимального використання наявної інфраструктури та меншого впливу на довкілля. Орієнтація розміщення вітроустановок прийнята з урахуванням домінуючих напрямків вітру.

Відстані між турбінами визначались, насамперед, 3 огляду на результати аналізу вітрових характеристик території та міркувань оптимізації розташування ВЕУ для зменшення тиску на довкілля, а 
також врахування візуального впливу на населення найближчих поселень та на туристів.

На майданчиках, у місцях розташування ВЕУ, передбачається тимчасове розміщення будівельних площадок для монтажу та обслуговування об'єктів. Уздовж рядів ВЕУ проектуються підземні кабельні та комунікаційні лінії і технологічні дороги, які відображено на схемах інженерних мереж.

\section{4. Дослідження впливу вітроенергетичних установок на підсистеми, яруси компартментів СЛК за допомогою програмного забезпечення SimaPro}

Після завершення вводу даних будується дерево процесів для виявлення слабких точок аналізу. За розрахунками Національної лабораторії США 3 питань розвитку відновлювальної енергетики (NREL) розрізняють зони постійного і тимчасового впливу. Зони постійного впливу становлять $1-2 \%$ загальної площі і включають ділянки, на яких облаштовуються фундаменти вітрових турбін, під'їзні дороги, підстанції, службові споруди і інші елементи інфраструктури. Зони тимчасового впливу займають від 1 до 6\% території вітропарку і пов'язані з облаштуванням тимчасових доріг для потреб будівництва і місць зберігання будівельних матеріалів і обладнання. Ті ділянки майданчиків ВEC, які залишаються поза впливом будівництва, можуть використовуватись для інших потреб, наприклад для вирощування сільськогосподарських культур або для випасу тварин ${ }^{23}$.

Серед основних джерел потенційного впливу ВЕС на довкілля варто виділити такі: візуальний вплив (на ландшафт), який полягає в тому, що на місцевості вітроенергетичні установки висотою до 150 м (з врахуванням обертання лопатей) проглядаються на значних відстанях та змінюють вигляд природного ландшафту матиме місце через можливість споглядання із смт. Воловець двох ВЕУ поблизу метеостанції Плай, решта ВЕУ (32 шт.) не видні із поселень, їх можуть бачити тільки особи, які знаходяться на Боржавських Полонинах у зоні планованої діяльності; мерехтлива тінь: обертання лопатей турбін за певних умов створює рухому тінь, яка могла би в окремих ділянках прилеглої території створювати дискомфорт для людини, однак iї прояв при рельєфі території планованої діяльності та положеннях сонцестояння стосовно спостерігача практично виключена; шумовий вплив та вібрація, що створюються під час обертання лопатей та роботи генераторів можуть негативно впливати на живі організми, а також спричинювати небажані геофізичні процеси, наприклад сходження снігових лавин у разі їх значної інтенсивності, однак для обраних

23 Дзензерский В.А. Ветроустановки малой мощности / В.А. Дзензерский, С.В. Тарасов, И.Ю. Костюков. Київ : Наук. думка, 2011. 592 с. 
сучасних типів ВЕУ прояв цих чинників незначний; електромагнітне випромінювання, джерелом якого $\epsilon$ не самі ВЕУ, а проектовані повітряні i кабельні лінії електропередач та трансформаторні підстанції, проектуються технічно і технологічно так, щоб убезпечити від цього впливу відповідно до чинних законодавчо-нормативних вимог як у відношенні впливу на довкілля так і для персоналу ВЕС та інших осіб, які можуть знаходитися поблизу ВЕУ та інженерних споруд; вплив на землекористування: певна площа земель буде зайнята в процесі будівництва стаціонарних і тимчасових об'єктів (вона становить 0,01 \% від загальної площі Боржавських Полонин), однак використані окремі ділянки вільні від лісових насаджень, не мають особливо цінної рослинності та оселищ тварин або гніздування птахів, вони $є$ незначними за площею, тому тимчасове порушення земель на період будівництва ВЕС не спричинить значного впливу на довкілля; вплив на флору та фауну міг би бути спричинений через порушення земель на яких наявні цінні види рослин або оселища тварин, через ризик загибелі птахів (зокрема, рукокрилих) при зіткненні з лопатями турбін ВЕУ, через вплив електромагнітного випромінювання, звукових хвиль, вібрації тощо; вплив на повітряне середовище матиме місце тимчасово тільки при роботі транспорту та іншої техніки в період підготовчих та будівельних робіт; викиди в атмосферу при стаціонарній роботі ВЕС не матимуть місця; вплив на водне середовище буде незначним у період підготовчих та будівельних робіт, а в період експлуатації ВЕС скидів у водне середовище не матиме місця, побутові потреби водозабезпечення привозною водою та водовідведення будуть здійснюватися без негативних наслідків для довкілля; вплив на безпеку життєдіяльності населення можливий у разі транспортуванні високо габаритного устаткування для ВEC, а також неналежного виконання чинного законодавства при реалізації проекту, заходи щодо запобігання прояву такого впливу передбачені технологічним процесом реалізації проекту.

\section{5. Оцінка в екобалах впливу кожного з етапів життєвого циклу ВЕУ на яруси і підсистеми компартменту СЛК}

Після закінчення побудови дерева проведено аналіз оцінки впливів на довкілля. Процес аналізу складався 3 таких п'яти елементів: характеризація; оцінювання шкоди; нормалізація; зважування; визначення екологічного індексу.

Аналіз життєвого циклу на основі характеризації - це групи входів і виходів, які розподіляються між одинадцятьма категоріями впливу відповідно до методології Есо-індикатора 99. Характеризація показує відносну силу небажаних впливів, кожен із відповідним матеріалом життєвого циклу та полягає у визначенні питомої ваги: канцерогенів, респіраторних речовин, змін клімату, радіації, впливу на озоновий шар, 
екотоксичність, викопних видів палива, змін у землекористуванні, мінералів, підкислення/евтрофікації (рис. 1). Всі від'ємні значення представляють заходи із запобігання викидів шкідливих речовин, тому ці значення свідчать про позитивні, бажані 3 точки зору стану навколишнього природного середовища процеси, тобто говорять про те, що речовини вловлюються або ж не викидаються у значних кількостях.

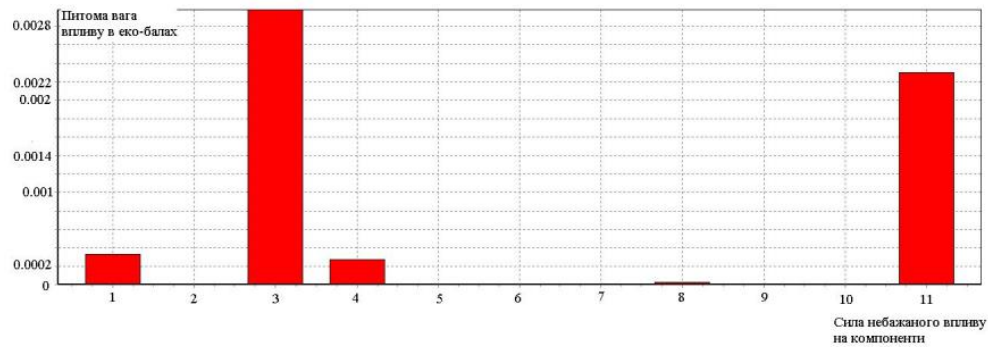

Рис. 1. Оцінка впливу ВЕУ на всіх етапах життєвого циклу в компартментах СЛК: 1 - канцерогенні речовини; 2 - респіраторні органічні сполуки; 3 - респіраторні неорганічні сполуки;

4 - кліматичні зміни; 5 - радіоактивні речовини; 6 - вплив на озоновий шар; 7 - екотоксини; 8 - підкислення/евтрофікація; 9 - ландшафтні (нематеріальні) ресурси; 10 - мінеральні ресурси; 11 - викопні джерела енергії

Як обчислювальні процедури, які використовуються для агрегування даних у впливі категорій, застосовуються екологічні моделі для порівняння різних внесків у ті самі екологічні проблеми. Це завдання може бути досягнуто за допомогою еквівалентності факторів, передбачених моделями.

3 цього графіка (рис. 1) визначено характерні результати специфікації впливу ВЕУ на всіх етапах життєвого циклу в компартментах СЛК. Це свідчить про те, що в деяких категоріях впливів домінує вплив на ландшафтні комплекси, в той час як наприкінці життєвого циклу домінують інші фактори, всі впливи відображені на 100\%-ій шкалі. Як видно з наведених вище графіків, найбільше негативних впливів на довкілля виникатиме від відходів, тобто викидів в атмосферу парникових газів, тому маємо відповідний вплив і на екотоксичність та зміни клімату. Це зумовлено тим, що потрапляння шкідливих парникових газів супроводжується таким явищем, як накопичення шкідливих речовин, які в результаті потрапляють у грунти, підземні та поверхневі води, а також призводять 
до значного забруднення атмосферного повітря, роблячи відповідний негативний внесок у зміни клімату.

Для отримання більш прозорих результатів АЦЖ можна всі впливи об'єднати в три категорії, а саме: здоров'я людини (канцерогени, респіраторні речовини, зміна клімату, радіація, озоновий шар, екотоксичність), якість екосистем (підкислення/евтрофікація, землекористування), природні ресурси (мінерали, викопні види палива).

На рис. 2 бачимо, що найбільший вплив ВЕУ на всіх етапах життєвого циклу в компартментах СЛК здійснюється на природні ресурси та здоров'я людей.

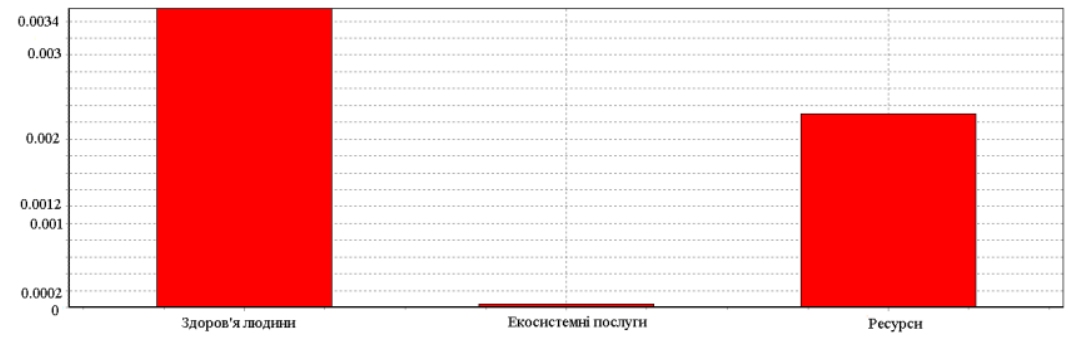

Рис. 2. Оцінка впливу ВЕУ на всіх етапах життсвого циклу в компартментах СЛК за трьома об'єднаними категоріями впливів на довкілля

Eco-індикатор 99 є одним із методів, який дає нам змогу прийняти одну оцінку для всього життєвого циклу - так званий екологічний індекс. Це сума всіх окремих екоточок або часткових індексів для всіх процесів життєвого циклу. Обчислювальна процедура здійснюється шляхом підсумовування результатів зважування фаз життєвого циклу. На рис. 3 представлені остаточні результати впливу всього життєвого циклу за допомогою екологічного індексу.

Варто зауважити, що життєвий цикл об'єктів вітроенергетики породжує неоднорідні за своїм впливом наслідки для компонентів ландшафту, так, екологічний індекс становить - 1,91. Вітровий парк, як будь-який інший об'єкт господарської діяльності, викликає зміни природних характеристик ландшафту та властивостей його компонентів, що призводить до формування техногенних геокомплексів ${ }^{24,25}$.

${ }^{24}$ Wind Power For Dummies [Published by Wiley Publishing], Inc. Indianapolis. 2009. 387 p.

${ }_{25}$ Chiras D. Wind Power Basics. / [New Society Publishers], Gabriola Island, Canada. 2010. 179 p. 
СЛК, в якій функціонують ВЕУ, - система, для якої характерна структурно-функціональна єдність взаємозв'язаних компонентів і цілісність біотичної та абіотичної складових частин. СЛК складається $3 n$ компартментів, пов'язаних між собою потоками речовини $f_{k i}$ ( 3 -го в $i$-й), кожен блок може приймати з навколишнього абіотичного середовища або інших компартментів потік $q_{i}$ а віддавати потік $y_{i}$. Як ціле реагують вони і на зовнішні впливи, насамперед, антропогенні. Простір для ландшафтознавства - це, передусім, територія, суцільно заповнена цими компартментами. Дослідити простір (територію) означає виділити ці компартменти ${ }^{26}$.

\section{6. Виявлення потенційного впливу об'сктів вітроенергетики на яруси підсистеми компартментів СЛК на всіх етапах його функціонування}

У результаті взаємодії природних компонентів і антропогенних чинників формується специфічна система складних ландшафтних комплексів різноманітного таксономічного рангу.

Проаналізувавши життєвий вплив вітряних турбін, можна визначити види робіт, що можуть впливати на компартменти СЛК: транспортування, будівництво та монтаж, експлуатація та технічного обслуговування, демонтаж.

Під час транспортування ВЕС здійснюється вплив на трунтоворослинний покрив шляхом порушення грунтово-рослинного покриву, ущільнення грунту, забруднення грунтів паливно-мастильними матеріалами, на водні об'єкти - через надходження завислих речовин, зливових стоків, зміни гідрохімічного режиму, змивання паливномастильних матеріалів із під’іздних шляхів, на тваринний світ - шум через присутність транспорту та людей, ураження та смертність тварин під час зіткнення з транспортними засобами, потрапляння інвазійних видів, на атмосферне повітря - пил від транспортного устаткування, викиди в атмосферу (пара, вихлопні гази, незгорілі вуглеводні, паливні випари);

Під час будівниитва та монтажу здійснюється вплив на водні об'єкти, оскільки будівництво та експлуатація ВЕУ не передбачає будь-якого довгострокового впливу на поверхневі або підземні водні ресурси. Розміщення ВЕУ не чинитиме негативного впливу на роботу водопровідних та каналізаційних мереж та не може порушити чинний гідрологічний та гідробіологічний режим поверхневих та підземних вод. Під час проведення будівельних робіт водопостачання на майданчик проекту буде організоване за допомогою мобільних цистерн. Під час експлуатації ВЕУ потреби в питному, гарячому водопостачанні та каналізації забезпечуватимуться автономними

${ }^{26}$ Бойко Т.Г., Паславський М.М., Руда М.В.Стійкість складних ландшафтних комплексів: формалізація моделі. Науковий вісник НЛТУ Украӥни : збірник науковотехнічних праць. 2019. Т. 29, № 3. С. 108-113. 
системами. Генерування електроенергії на ВЕУ відбувається без використання водних ресурсів. Під час будівництва та експлуатації ВЕУ впливу на поверхневі водойми не створюється, оскільки в технологічному процесі вода з місцевих джерел не використовується, а потічків, річок озер поблизу будівельних майданчиків немає. Вплив у разі виникнення аварійних ситуацій виключений, тому що в зоні розміщення ВЕУ поверхневі води відсутні.

Будівництво або промислова діяльність будь-якого роду має потенціал впливу на ресурси трунту (екскавація), піску і гравію (видобування), а також джерела інших порід. Ці дії можуть відбуватися в межах певної площі будівництва в результаті розробки грунту, його вирівнювання i тому подібного або в межах ширшої території в результаті виїмки грунту i використання будівельних матеріалів. Основний вплив на геологічне середовище буде мати місце тільки тимчасово під час виконання будівельних робіт. У транспортуванні необхідного устаткування та техніки (складові частини ВЕУ, збірні два основні та допоміжний крани, а також бетон для фундаментів тощо) велике значення відіграють надійні дороги. Їх будівництво є одним із найбільш важливих чинників впливу на природне середовище. Інший можливий вплив на геологічне середовище створюватиметься земляними роботами, які необхідно виконати для облаштування фундаментів під башти ВЕУ. Необхідна виїмка значного обсягу грунту iз котлованів. Частина грунту (найбільш родюча) буде використана для покриття фундаментів ВЕУ при рекультивації. Інша, гірша частина грунту використовуватиметься для відновлення ділянок, 3 яких здійснюється виїмка матеріалу для облаштування фундаментів або для відновлення інших пошкоджених ділянок території. Виїмка грунту проводитиметься з урахуванням вказівок виробника ВЕУ i, з огляду на місцеві геофізичні умови, так щоб гарантувати безпеку ВЕУ і водночас звести до мінімуму вплив на довкілля.

Інший вплив на геологічне середовище можливий при експлуатаціï ВЕУ внаслідок вібрації. При цьому джерелом вібрації є рухомі частини ВЕУ, a саме лопаті ротора. За підтвердженими на практиці розрахунками, конструкція ВЕУ не передає вібрації на навколишню територію за умови, що вага ії нерухомої частини в 16 і більше разів перевищує вагу іiі рухомої частини. Вага частин ВЕУ, що обертаються, запроектованих для установки, становить приблизно 15 тонн, а вага нерухомої частини - комплексу фундамента ВЕУ - близько 400 тонн. Отже, вага нерухомої частини понад ніж у 20 разів перевищує вагу рухомої частини. Тому вібрація (спричинена елементами ВЕУ, що обертаються) практично повністю затухає на масивній основі фундаменту і не передається геологічному середовищу.

У процесі будівництва ВЕУ електричні мережі будуть виконані кабельними лініями, прокладеними на глибині від 1,0 м до 2,0 м 
залежно від глибини промерзання грунту, рівня напруги, пересічення інженерних комунікацій.

Інший можливий вплив створюватиметься земляними роботами, необхідними для облаштування фундаментів для ВЕУ. Вони припускають виїмку значного обсягу грунту. Частина грунту (найбільш родюча) буде збережена для рекультивації майданчика по завершенню будівництва. Інша частина грунтів буде використана для покриття фундаментів ВЕУ. Залишок неякісних грунтів використовуватиметься для відновлення ділянок, 3 яких здійснюється виїмка матеріалу для облаштування фундаментів або відновлення інших пошкоджених ділянок території.

У процесі експлуатаиіï ВЕУ впливу на повітряне середовище, клімат та мікроклімат не створюється. Навпаки, виробництво електроенергії $з$ використанням енергії вітру дає змогу запобігти забрудненню атмосферного повітря, порівняно 3 виробництвом електроенергії тепловими електростанціями, рівно на величину викидів ТЕС.

Найбільше занепокоєння щодо впливу ВЕУ на об'єкти фауни пов'язане з ризиком для птахів і рукокрилих при зіткненні з турбінами, тоді як вібрація і втручання в середу мешкання розглядається як незначна загроза для флори і фауни в регіоні. За даними Датської Національної Лабораторії RISO, випадки загибелі птахів на високовольтних дротах і від зіткнення з автомобілями є в 100 разів частішими, ніж їх загибель від лопатей ВЕУ.

На території планованої діяльності немає територій та об'єктів, що включені до природно-заповідного фонду загальнодержавного або місцевого рівнів. Найближчими до майданчиків планованої ВЕУ $€$ загальнозоологічний заказник загальнодержавного значення «Потік Оса», який розташовано на відстані більше 2 км від самого потоку Оса, що сам віддалений від території ПД, тому не може йтися про порушення його охоронного зобов'язання від 19.07.2012 р., виданого Держуправлінням охорони навколишнього природного середовища в Закарпатській області.

Процес демонтажу супроводжується впливом на: трунтоворослинний покрив шляхом забруднення грунтів паливно-мастильними матеріалами; водні об'єкти - забруднені поверхневими стоками 3 території вітропарку, спостерігається підвищення утворення осаду у водних об'єктах, забруднення водних об’єктів вуглеводнями від транспортних засобів; тваринний світ - перешкодження вільному переміщенню та міграції видів через присутність транспорту та людей; атмосферне повітря - пил від транспортного та будівельного устаткування, вихлопні гази.

\section{7. Обговорення результатів впливу життєвого циклу вітроенергетичних установок в компартментах складного ландшафтного комплексу}

Отримані результати пояснюються дослідженням процесів зародження, функціонування та занепаду ландшафтно-інженерних та 
ландшафтно-техногенних систем і їх впливу на довкілля, що дасть змогу прослідкувати розвиток усіх притаманних цим системам процесів та виявити можливі наслідки. Оскільки деградація або навіть незначне порушення одного з природних компонентів ландшафту може призвести до значних змін у всьому ландшафтному комплексі, аж до його повного знищення, було вивчено можливі впливи об'єктів вітроенергетики та компоненти ландшафту на різних етапах життєвого циклу, узагальнення яких дало змогу розробити попереджувальні та пом'якшувальні заходи щодо уникнення екологічних наслідків у майбутньому.

Пропонована в роботі оцінка життєвого циклу дає змогу виявити потенційні впливи об'єктів вітроенергетики на яруси підсистеми компартментів СЛК на всіх етапах його функціонування - від етапу видобутку корисних копалин для виготовлення складових частин до моменту повної утилізації вітрової турбіни після закінчення терміну іiі експлуатації, порівняно 3 традиційним підходом, який передбачає дослідження впливів об'єкта на довкілля під час його безпосередньої експлуатації.

Описана вище методика оцінки життєвого циклу 3 отриманням показників впливу на компоненти довкілля в екобалах дала змогу зінтегрувати масив знань щодо впливу 3 боку ВЕУ на яруси і підсистеми компартментів СЛК у прагненні використати ці показники для формування нормативного забезпечення якості їх функціонування. Конкретизувавши ситуацію для СЛК, визначили, що центральним поняттям такої системи $є$ компартмент, який піддається екологічному навантаженню 3 боку ВЕУ. Серед основних груп впливів можна виділити підгрупи основних i корелятивних параметрів. Під час здійснення аналізу життєвого циклу ВЕУ на компартменти СЛК були зроблені такі істотні спрощення і припущення: всі міркування ведуться за припущення, що компартмент СЛК як у фоновому, так і в трансформованому стані відповідає класам стійкості та перебуває в стаціонарних режимах функціонування (це дає змогу редукувати залежності: доза $\rightarrow$ час $\rightarrow$ ефект до залежностей: доза $\rightarrow$ ефект); схема досліджень для фонового стану може бути коректно здійснена лише в тому компартменті, де яруси та підсистеми знаходяться в фоновій зоні толерантності, а діагностичні ознаки мінімального відхилені від середніх значень.

\section{ВИСНОВКИ}

1. Встановлено, що сучасні вітчизняні екологи, географи, ландшафтознавці не приділяють належної уваги впливу різних видів альтернативних джерел енергії на компартменти складного ландшафтного комплексу.

2. Досліджено, що з технічної та економічної точки зору вітрова енергія $\epsilon$ найбільш розвиненою та використовуваною формою 
відновлювальної енергії, а з екологічної - чинить найменший вплив на підсистеми, яруси компартментів СЛК та може ефективно сприяти боротьбі зі змінами клімату і разом із тим забезпечувати досягнення еколого-економічних та соціальних вигод.

3. Визначено, що найбільш значні наслідки для ярусів підсистем компартментів СЛК виникають на етапі транспортування, установки і монтажу ВЕС. Разом із тим етап безпосередньої експлуатації ВЕУ майже не відображається на стані СЛК загалом, але має вплив на підсистеми компартменту.

4. АЖЦ дає змогу виявити потенційні впливи об'єктів вітроенергетики на яруси підсистеми компартментів СЛК на всіх етапах його функціонування - від етапу видобутку корисних копалин для виготовлення складових частин до моменту повної утилізації вітрової турбіни.

\section{АНОТАЦІЯ}

Встановлено, що методика аналізу життєвого циклу базується на оцінці вхідних та вихідних матеріальних потоків одиничних процесів, а також можливих впливах на стан навколишнього природного середовища на всьому етапі життєвого циклу продукції. Аналіз життєвого циклу моделює життєвий цикл продукту у вигляді його функціональної системи. Визначено, що функціональна система вітроенергетичної установки $\epsilon$ сукупністю одиничних процесів, які поєднуються між собою потоками півфабрикатів та елементарними потоками 3 навколишнього середовища. Компоненти схем пов'язані між собою транспортними потоками. Дослідження процесів зародження, функціонування та занепаду ландшафтно-інженерних та ландшафтно-техногенних систем i їх впливу на довкілля дасть змогу прослідкувати розвиток усіх притаманних цим системам процесів та виявити можливі наслідки. Здійснено аналіз оцінювання впливу вітроенергетичних установок на всіх етапах життєвого циклу в компартментах складного ландшафтного комплексу за допомогою програмного забезпечення SimaPro. Визначено, що найбільш значні наслідки для ярусів підсистем компартментів виникають на етапі транспортування, установки i монтажу вітряних турбін. Описана дослідженні методика оцінки життєвого циклу 3 отриманням показників впливу на компоненти довкілля в екобалах дала змогу зінтегрувати масив знань щодо впливу 3 боку вітроенергетичних установок на яруси i підсистеми комапартментів складного ландшафтного комплексу в прагненні використати ці показники для формування нормативного забезпечення якості їх функціонування. 


\section{ЛIТЕРАТУРА}

1. Перспективы мировой ветроэнергетики. Доклад GWEC, Greenpeace International, DLR и Ecofys Cpnsultancy / под ред. Crispin Aubrey, Angelika Pullen, Arthouros Zervos, Sven Teske, Berlin. 2007. 31 c.

2. Алёшин Д.В.Проблемы развития альтернативной энергетики: правовой аспект. Журнал ЭГО. 2012. № 3. С. 10-12.

3. Леже С. «Зеленая лихорадка»: инвестиции в новую енергетику. Вестник McKinsey. 2008. № 3. C. 10-15.

4. Ратнер С.В., Иосифов В.В. Формирование рынков энергетического машиностроения в Китае и Индии. Вестник УРФУ, Серия «Экономика и управление». 2013. № 3. С. 52-62.

5. Muñoz I, Schmidt J, Brandão M, Weidema B P. Rebuttal To 'Indirect Land Use Change (Iluc) Within Life Cycle Assessment (Lca) - Scientific Robustness And Consistency With International Standards'. Gcb Bioenergy, Letter To Editor, 7(4), 2015. P. 565-566.

6. Weidema B.P. Attributional And Consequential Interpretations Of The Iso 14044. Historical Snapshot From The Work In Iso. 2018. Tc207/Sc5/Tg1.

7. Nishioka Y., Levy J.I, Norris G.A, Wilson A, Hofstetter P, Spengler J.D. Integrating Risk Assessment And Life Cycle Assessment: A Case Study Of Insulation. Risk Analysis 22(5). 2002. P. 1003-1017.

8. Бойко Т.Г., Руда М.В., Паславський М.М., Соколов С.О., Петренко С.В., Скаковський С.I. Кібернетична природа складних ландшафтних комплексів та супра-оптимізація механізмів самовідновлення та самозбереження. Науковий вісник НЛТУ Украӥни : збірник науково-технічних праць. 2019. Т. 29, № 5. С. 134-140.

9. Obshta, A.; Bubela, T.; Ruda, M.; Kochan, R. THE MODEL OF ENVIRONMENTAL ASSESSMENT OF COMPLEX LANDSCAPE SYSTEMS International Multidisciplinary Scientific GeoConference : SGEM; Sofia Том 18, Изд. 3.2, : 973-979. Sofia: Surveying Geology \& Mining Ecology Management (SGEM). DOI: 10.5593/sgem2018/3.2/ S14.125.

10. Безруких П.П. Использование энергии ветра. Техника, экономика, экология. Москва : Колос, 2008. 196 с.

11. Ветроэнергетика / под ред. Д. де Рензо; пер. с англ. Зубарева В.В. и Дранкфурта М.О.; под. ред. Шефтера Я.И. Москва : Энергоатомиздат, 2010. $287 \mathrm{c}$.

12. Cleary B. Using life cycle assessment ro compare wind energy infrastructure / B. Cleary, A. Duffy, A. O'Connor. Proceedings of International Symposium on Life Cycle Assessment and Construction. 2012. P. 31-39.

13. Life cycle assessment of a multi-megawatt wind turbine / E. Martinez, F. Sanz, S. Pellegrini [et. Al]. Renewable Energy. 2009. № 34(3). P. 667-673. 
14. Chenai Ch. Life cycle analysis of wind turbine. Sustainable Development - Energy, Engineering and Technologies - Manufacturing and Environment. 2012.

15. Toth T. Anthropogeomorphologic impacts of onshore and offshore wind farms / T. Toth, S. Szegedi. Acta climatologica et chorologica. 2007. № 40-41. P. 147-154.

16. Єрмоленко Б.В., Ермоленко Г.В., Рыженков М.А. Экологические аспекты вітроенергетики. Теплоэнергетика. 2011. № 11. С. 72-78.

17. Final Report. Life Cycle Assessment Of Electricity Production from a Vestas V112 Turbine Wind Plant. 2011. http://www.vestas.com.

18. База даних «EcoIvent». URL: http://www.ecoivent.org/.

19. Burton T., Sharpe D., Jenkins N., Bossanyi E. (2001), Wind energy. Handbook / [West Sussex], England, 643 p.

20. Chmielniak, T. (2008). Technologie energetyczne. [Wydawnictwa NaukowoTechniczne], Warszawa. 564 p.

21. Забарний Г.М. Енергетичний потенціал нетрадиційних джерел енергії України / Г.М. Забарний, А.В. Щурчков. Київ : ІТТФ, 2002. C. 151-159.

22. Der Strommix in Deutschland im Jahr 2012. AGEB. URL: http://www.unendlich-viel-energie.de.

23. Дзензерский В.А. Ветроустановки малой мощности / В.А. Дзензерский, С.В. Тарасов, И.Ю. Костюков. Київ : Наук. думка, $2011.592 \mathrm{c}$.

24. Ветроэнергетика Украины. URL: http://www.uwea.com.ua/ ukraine_wind.php.

25. Wind Power For Dummies [Published by Wiley Publishing], Inc. Indianapolis. 2009. 387 p.

26. Chiras D. Wind Power Basics. / [New Society Publishers], Gabriola Island, Canada. 2010. 179 p.

27. Бойко Т.Г., Паславський М.М., Руда М.В. Стійкість складних ландшафтних комплексів: формалізація моделі. Науковий вісник НЛТУ Украӥни : збірник науково-технічних праць. 2019. Т. 29, № 3. С. 108-113.

Information about authors: Ruda M. V.,

Candidate of Technical Sciences, Assistant of Department of Ecological Safety and Nature Protection Activity Lviv Polytechnic National University, 12, S. Bandera str., Lviv, 79013, Ukraine

Hyvlyud A. M., $\mathrm{PhD}$, Assistant of Department of Ecological Safety and Nature Protection Activity Lviv Polytechnic National University, 12, S. Bandera str., Lviv, 79013, Ukraine 